\title{
Traditional Pathway of Oil Extraction from Quassia undulata Seeds and Its Chemical Characteristic
}

\author{
Ndiaye Seyni'1,2, Gueye Mathieu ${ }^{3}$, Baldé Samba ${ }^{1,2}$, Ndiaye Bou ${ }^{1,2}$, Ayessou Nicolas Cyrille ${ }^{1,2 *}$ \\ ${ }^{1}$ Laboratoire Eau-Energie-Environnement et Procédésindustriels (LE3PI), ESP-UCAD, Dakar, Sénégal \\ ${ }^{2}$ Center for Studies on Food Safety and Functional Molecules (CESAM-RESCIF), ESP-UCAD, Dakar, Sénégal \\ ${ }^{3}$ Laboratoire UMI 3189, Bp206 Dakar, Département de Botanique et de Géologie, Institut Fondamental d'Afrique Noire (IFAN), \\ Cheikh Anta Diop University, Dakar, Sénégal \\ Email: ^nayessou@yahoo.fr, *nicolas.ayessou@ucad.edu.sn
}

How to cite this paper: Seyni, N., Mathieu, G., Samba, B., Bou, N. and Cyrille, A.N. (2021) Traditional Pathway of Oil Extraction from Quassia undulata Seeds and Its Chemical Characteristic. Food and Nutrition Sciences, 12, 452-461.

https://doi.org/10.4236/fns.2021.125035

Received: April 19, 2021

Accepted: May 23, 2021

Published: May 26, 2021

Copyright $\odot 2021$ by author(s) and Scientific Research Publishing Inc. This work is licensed under the Creative Commons Attribution International License (CC BY 4.0).

http://creativecommons.org/licenses/by/4.0/

\begin{abstract}
In Africa, traditional vegetable oil extraction often involves the use of plants in the manufacturing process. Quassia undulata oil is thus traditionally prepared. An expedition went to Kédougo (a region in southeastern Senegal involving women of the Bassaris community) in June 2018 to study the Q. undulata oil traditional extraction mode. Thus, the objective of this study is to follow the traditional extraction of $Q$. undulata oil and to perform the physico-chemical analysis of the obtained oil. Oil samples taken after the survey allowed the oil physico-chemical characterization. The traditional oil extraction made by four women from Eganga, Ethiolo, and Ebarack's villages reveals oil clear that is solid at room temperature. The study of the established chart revealed the use of Pilliostigma thonnintigi leaves during the oil preparation. The oil shows characteristics comparable to shea butter, and the oil stability can be compared to the corn and peanut oil one. The physicochemical analysis showed oil solid at room temperature with an acid value between $1.223 \pm 0.013$ and $7.333 \pm 0.465$. The saponification value was between 190.489 \pm 3.083 and $199.732 \pm 3.107$, and the peroxide value between $4.453 \pm 0.042$ and $8.644 \pm 0.285$. The iodine values were between $21.455 \pm 2.440$ and 38.068 \pm 0.082 , and the refractive index $1.462-1.463$. Q. undulata oil offers several technological perspectives. However, it would be interesting to study the impact of $P$. thonnintigi leaves during extraction. The fatty acid profile should also be determined.
\end{abstract}

\section{Keywords}

Quassia undulata, Traditional Extraction, Physico-Chemical Characterization 


\section{Introduction}

Senegal, located in the west of Africa, is full of many potentialities. In the most remote areas of the country, the local population exploits the forest resources in their daily lives ranging from firewood to wild fruits [1]. In the Sahelian and Sudanian regions, Adansonia digitata L., Balanites aegyptiaca L., Tamarindus indica $L$. are commonly used [2] meanwhile genus Carapa (Meliacéa) in the south and east are useless [3] [4]. Such non-conventional forest resources have many potentialities which are important to study. In the department of Salemata, women exploit seeds of $Q$. undulata to extract oil [5]. A survey made in the central area of Senegal (Bassin arachidier) shows that $Q$. undulata is used as food (fruits) and in wood production [1]. The $Q$. undulata seeds are known to have potential nematocidal activity on Meloidogyne javanica juveniles [6] [7]. In Nigeria, Q. undulata leaves were effective for the management of cognitive disorders [8]. Elsewhere, $Q$. undulata aqueous leaf extracts were proved to prevent scopolamineinduced amnesic effects in rats [9]. Only the investigations of Mirailles et al., 1988 [10] dealt with fatty acids found in the oil of Q. undulata. The traditional production of this oil reveals the enhancement of local know-how. Traditional oil extraction is made by women and used as a skin ointment and as a medicine against earache. However, there is no booked information about this typical extraction. Thus, an expedition was organized in Kédougou, and physicochemical analysis has been done to complete previous studies of Mirailles et al., 1988 [10].

\section{Materials and Methods}

\subsection{Survey Process}

The investigations were carried out into three villages: Eganga, Ethiolo, and Ebarack, located in the department of Salemata in Kedougou-Senegal in June 2018 (Figure 1). The process monitoring was done at the level of 04 women: 02 in the Eganga's village, 01 in the Ethiolo's village, and 01 in the Ebarack's village.

The survey consisted of recording the oil process made by women. The objective is to watch the women making the oil process as they do in their daily lives and then identify all the involved steps. After each procedure, oil and oilcake samples were taken for further analysis. Six oil samples were obtained and distributed as follow:

1) In Eganga, two oil samples were obtained prepared by two women: one sample per woman;

2) At Ebarack, two oil samples were obtained made by the same woman. The first one was prepared following the normal diagram process, and the second one was prepared without modifications;

3) At Ethiolo, two oil samples were obtained prepared by the same woman: one of the oil extraction was made in 2017, and the second one was prepared in our presence. 


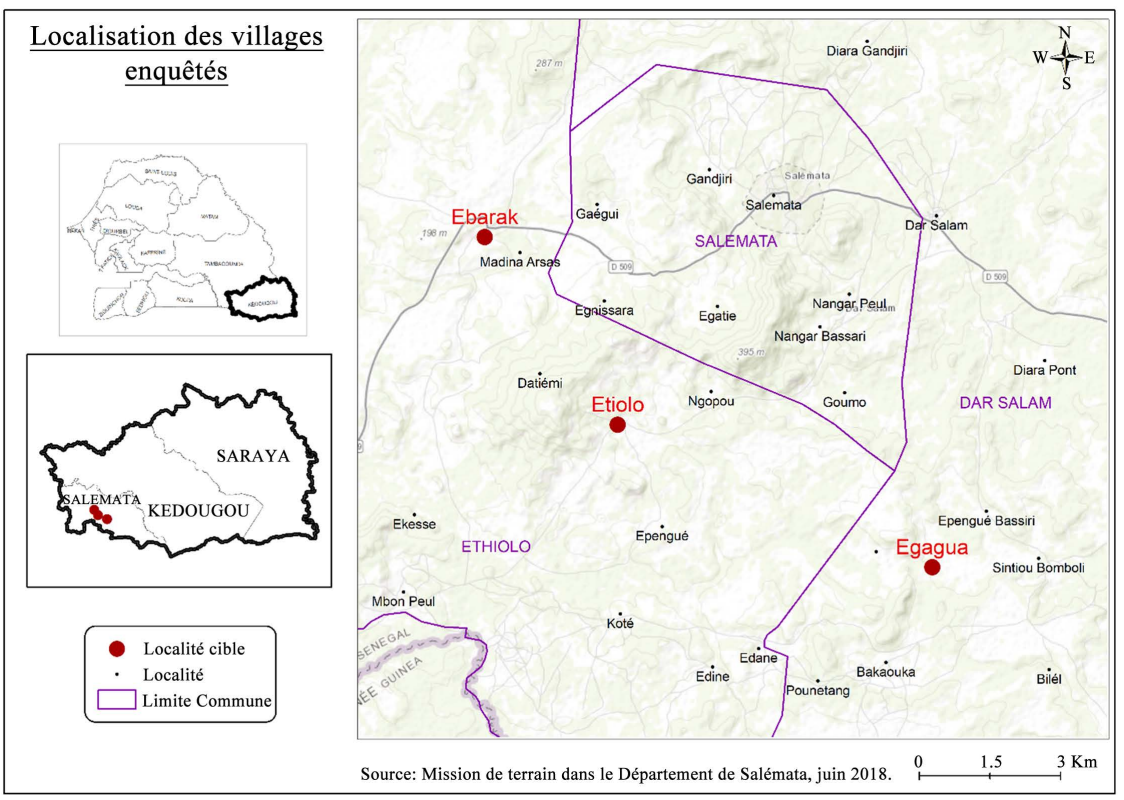

Figure 1. The villages' location where the surveys were conducted.

\subsection{Physicochemical Analysis}

The six samples were subjected to chemical analysis. All the analysis was done in duplicate, and the results were given as mean \pm standard deviation. The acid index was determined according to the standard method NF ISO 660, while the Iodine index was conducted according to the standard method NF ISO 3961. The standard method NF ISO 3657 method was used to determine saponification index and NF ISO 3960 for peroxide index. The refractive index was determined on the perfectly anhydrous and filtered sample according to standard method NF ISO 6320 with a refractometer.

\section{Results and Discussion}

\subsection{Quassia undulata Seed Oil Process Diagram}

The oil production began with the crushing step. The seeds of Quassia undulata, also called "Agnarka" in the Bassari language, were separated from their hulls (Figure 2(a)). This step was complicated and took a lot of time because the crushing is done with the teeth. After that, seeds were crushed, pounded, and sieved. During the third step, a decoction of $P$. thonningii leaves was produced. $P$. thonnintigi was poured into the water, and as soon as the boiling' began, the leaves were removed (Figure 2(b)). The seed's powder was then added to the decoction (Figure 2(c)). The Boiling continued until oil appears (fourth step). As soon as the quantity of oil was large enough, it was recovered using a spoon (Figure 2(c)). The last step was optional and consisted of a slight heating (Figure 2(d)) of the oil to eliminate traces of water in order to allow better conservation.

After oil recovery, the oilcake was processed to obtain pasta named "Enangue". The oilcake was first poured into a large basket with holes (Figure 3(a)). It 


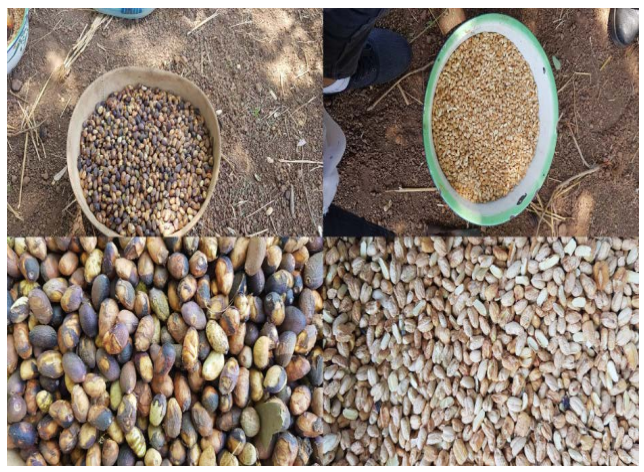

(a)

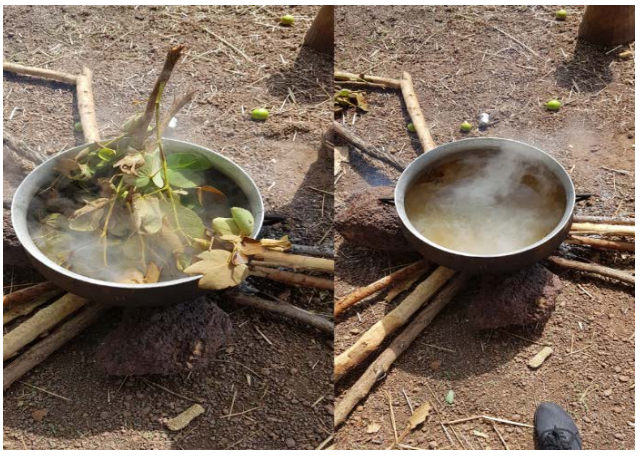

(b)

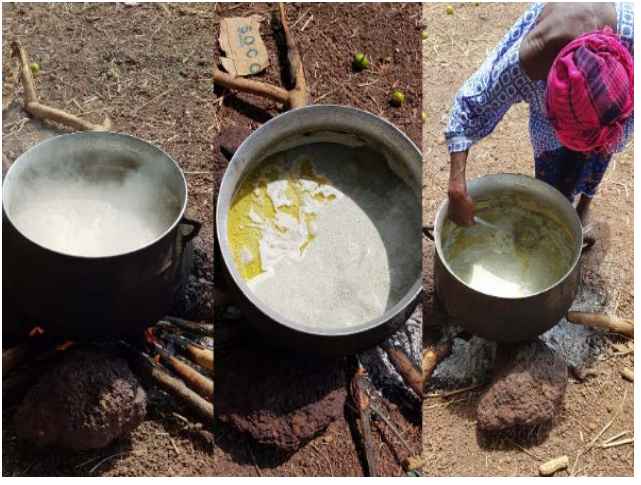

(c)

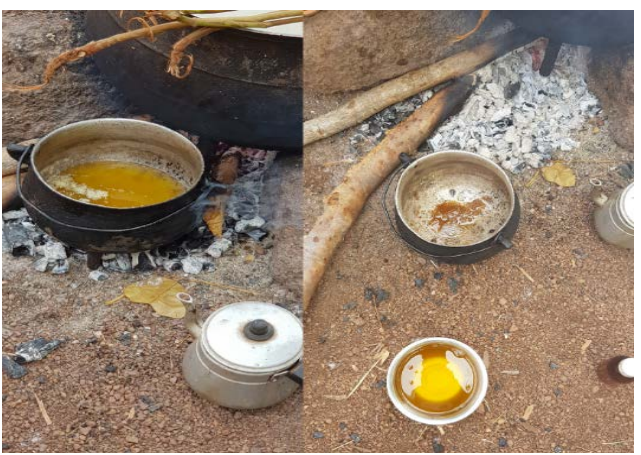

(d)

Figure 2. Panoramic of different steps of oil extraction from $Q$. undulata seeds. (a): $Q$. undulata seeds with hulls, (a1) and without hulls (a2); (b): Preparation of $P$. thonningii decoction; (c): Boiling step and oil recovering (the Quassia seeds powder is poured inside Pilliostigma decoction and boiled till oil formation); (d): Oil boiling step to remove water. 


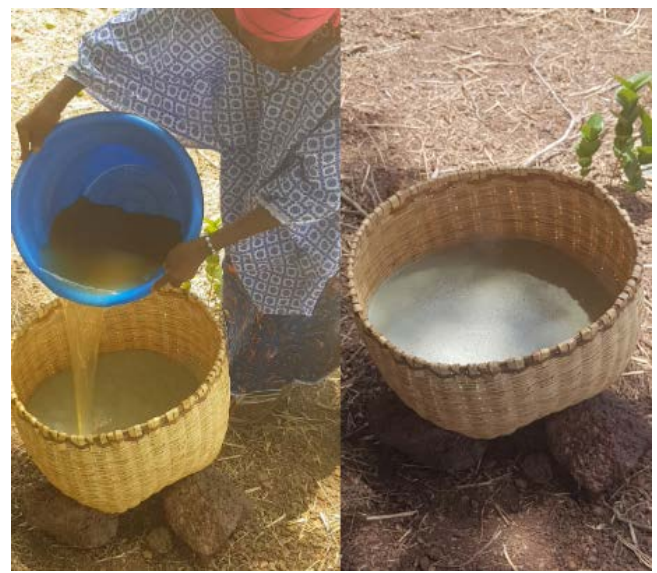

(a)

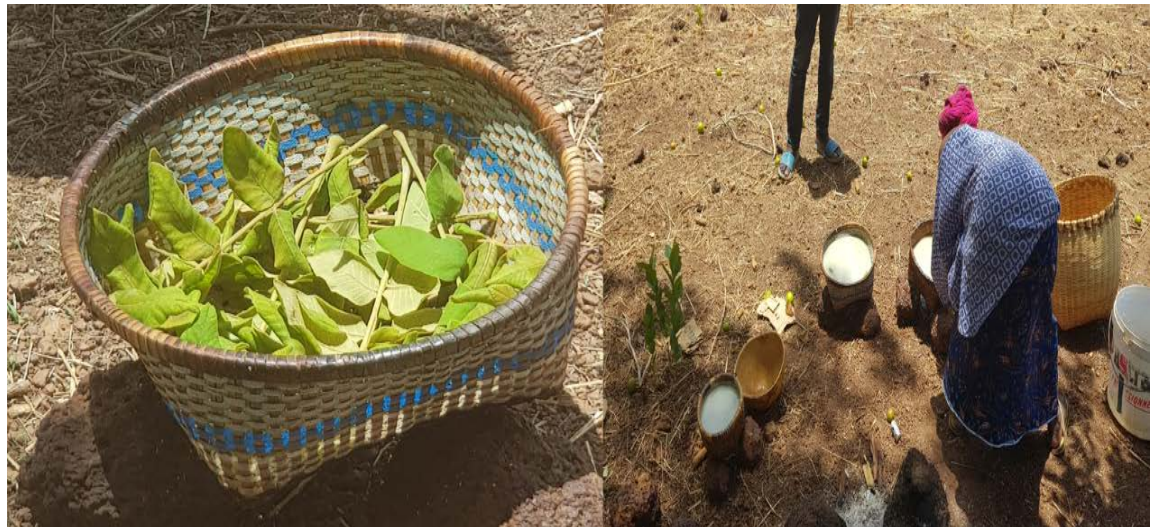

(b)

Figure 3. Pictures showing Quassia undulata oilcake process. (a): The washing step of the oilcake with $P$. thonningii decoction; (b): Water washing and dewatering step of the oilcake (left picture shows Lannea vellituna leaves added to the bottom of the small basket before poring the oilcake inside, and the right picture shows oilcake in small baskets).

was washed with a decoction of $P$. thonningii and then with water. During the second step, the oilcake was poured into small baskets with holes having Lanea velituna leaves at the bottom (Figure $3(\mathrm{~b})$ ). Water was then gradually poured onto the oilcake and was drained (dewatering step). Finally, after water draining, the baskets were left in the open air to dry the oilcake at normal environment temperature. When the oilcake was completely dewatered, the obtained dough called "Enangue" (Bassari language) was consumed with sugar or salt.

The monitoring of manufacturing processes by the four women from Eganga, Ethiolo, and Ebarack's villages gave rise to the diagram in Figure 4.

In Africa, different vegetable oils are extracted in traditional mode. Many of these methods include a mix of the seed powder with water at room temperature; for example, in Morocco, argan oil is traditionally obtained by crushing the seeds in a stone wheel, then the almond paste is added with water and mixed with the hand to express the oil [11]. Elsewhere the traditional oil extraction consists of oilseeds boiling with water to separate the oil from the ashes. It's the case of Elaeis guineensis and Butyrospermum parkii oil extraction [12]. The same 

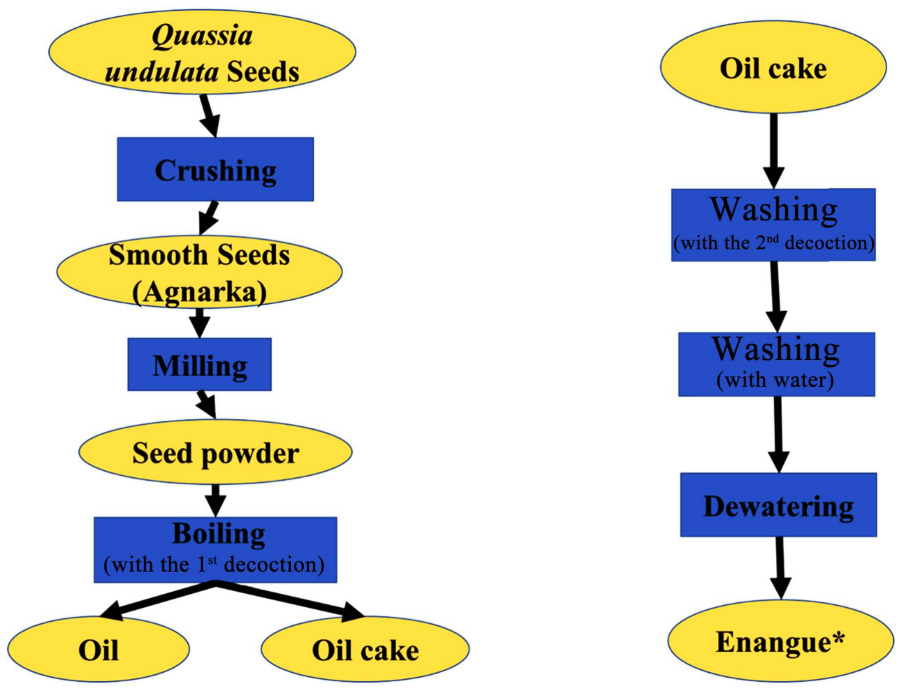

Figure 4. Quassia undulata oilseed and oil cake process ( $1^{\text {st }}$ decoction refers to Pilliostigma leaves boiled with water and the $2^{\text {nd }}$ decoction refers to the Pilliostigma milled leaves mixed with water at room temperature).

method is used for the traditional production of the Carapa (Carapa spp. Meliaceae) oil produced in West Africa, known to have a bitter taste [4]. However, Weber et al., 2010, during this survey, show that some plant particles were added by some women (optional) during the boiling step [4]. The Bassaris women used the same process in Kedougou to extract the Q. undulata seed oil. Mirailles et al., 1988 during their study about the Q. undulata fatty acid and quassinoids contents, used the Soxhlet mode with hexane as a solvent to extract oil from the seed. They obtain oil with a slightly bitter taste contrary to the oil obtained in this study using traditional extraction in the presence of $P$. thonnintigi leaves. Therefore, many questions arise about the $P$. thonnintigi key role during oil extraction. Are $P$. thonnintigi leaves responsible for the absence of bitter taste? Quassinoids are known as bitter principles [13], and Mirailles et al., 1988, in their study, show that $Q$. undulata oil is rich in quassinoids compounds (Klaineanone, Glaucarubolone, and Chapparinone). Therefore in the future, more analysis can focus on the research of quassinoids contents of $Q$. undulata oil obtained after this traditional extraction using $P$. thonnintigi leaves.

\subsection{Quassia undulata Seed Oil Physicochemical Characterization}

Oil samples obtained during the survey were subject to different physicochemical analyses. The results are shown in Table 1.

Table 1 shows that the peroxide indexes are lower than $10 \mathrm{mEq} / \mathrm{kg}$ for all the oil samples, indicating low oxidation according to the WHO/FAO limits that considered that rancid oil peroxide value is between 20 and $40 \mathrm{mEq} / \mathrm{kg}$ [14]. The refraction index and saponification value are quite identique. The refraction index is about 1.46, showing that the Quassia oil is non-siccative oil. The saponification value is between $197 \mathrm{mg} / \mathrm{g}$ and $198 \mathrm{mg} / \mathrm{g}$ for Eganga's and Ebarack's samples and between $190 \mathrm{mg} / \mathrm{g}$ for the oil sample from Ethiolo. These differences 
Table 1. Quassia undulata seed oil physical-chemical characterization summary.

\begin{tabular}{lccccc}
\hline Localities & $\begin{array}{c}\text { Refraction } \\
\text { value }\end{array}$ & $\begin{array}{c}\text { Acid value } \\
(\mathrm{mg} / \mathrm{g})\end{array}$ & $\begin{array}{c}\text { Saponification } \\
\text { value }(\mathrm{mg} / \mathrm{g})\end{array}$ & $\begin{array}{c}\text { Peroxyde } \\
\text { value }(\mathrm{mEq} / \mathrm{kg})\end{array}$ & $\begin{array}{c}\text { Iodine } \\
\text { value }(\mathrm{g} / 100 \mathrm{~g})\end{array}$ \\
\hline Eganga 1 & $1.46 \pm 0.00$ & $1.22 \pm 0.01$ & $197.64 \pm 0.37$ & $7.92 \pm 0.57$ & $38.07 \pm 0.08$ \\
Eganga 2 & $1.46 \pm 0.00$ & $4.23 \pm 1.77$ & $199.73 \pm 3.11$ & $8.64 \pm 0.28$ & $36.17 \pm 1.69$ \\
Ebarack & $1.46 \pm 0.00$ & $3.07 \pm 0.55$ & $198.34 \pm 2.26$ & $4.45 \pm 0.04$ & $30.04 \pm 0.07$ \\
Ethiolo & $1.46 \pm 0.00$ & $2.32 \pm 0.44$ & $190.49 \pm 3.08$ & $5.64 \pm 0.30$ & $31.61 \pm 1.66$ \\
\hline
\end{tabular}

can be explained by the boiling step used by the woman in Ethiolo after the oil recovering because the saponification value can decrease with the oil refinery step [15]. The acid values of samples are low and quite similar (1.22 - 4.21 $\mathrm{mg} / \mathrm{g}$ ). The small iodine value (from 30.04 to 38.07) may be due to Quassia oil small unsaturated acid contain [16]. This agrees with the results of Mirailles et al., 1988 in their study about the Q. undulata oil fatty acid content where it is showed that the oil is rich in saturated fatty acid [10]. The Quassia oil sample in this survey is solid at room temperature of $20^{\circ} \mathrm{C}-24^{\circ} \mathrm{C}$.

During the survey, it appears during the women's interview that the oil was used as a skin ointment after oil extraction. So, we compared Quassia oil's physico-chemical composition to shea butter, known as a high-quality skin ointment. The results are given in Table 2. Quassia undulata oil and shea butter are both solid at room temperature, and the iodine value and saponification value are similar. However, the peroxide value and the acid value of Quassia undulata oil are lower than the shea butter ones. According to that, Quassia undulata oil stability can be higher than shea butter.

On the other hand, Mirailles et al., 1988 after their study on the fatty acid and quassinoid content, concluded that Quassia oil could be used as cooking oil (only after removing the Quassinoids from the oil). So, Quassia oil's physicochemical oil composition was compared with the peanut and corn oil (Table 2). It is noticed that Quassia oil iodine value is lower than the peanut and corn oil one. Besides, Quassia oil is solid at room temperature, contrary to corn and peanut oil at room temperature. It means that Quassia oil's unsaturated fatty acid content is lower than corn and peanut oil. The three oils have almost the same refractive index. The Quassia oil saponification value is higher than the peanut and corn oil ones. The 03 oil peroxide values are lower than $10 \mathrm{mEq} / \mathrm{kg}$, showing that Quassia oil stability can be compared to the corn and peanut oil one.

Table 3 gives a comparison between $Q$. undulata produced in Senegal and $Q$. undulata made in Nigeria. It is noticed a difference between the results obtained in the 02 studies. The saponification value, iodine value, and refractive index are very different except for the peroxide and the acid value. This can be due to the production location; in the study of [20], the Moringa stenopetala oil saponification value and iodine value varied according to the sampling location. Besides, the peroxide value and the acid value were similar. On the other hand, the differences can be explained by the extraction mode. The $Q$. undulata oil characterized by Oko et al. [21] was extracted using a soxhlet extractor and hexane as 
Table 2. Physicochemical comparison between Quassia oil, peanut oil and corn oil.

\begin{tabular}{ccccc}
\hline Physicochemical properties & $\begin{array}{c}\text { Quassia } \\
\text { undulata oil }\end{array}$ & $\begin{array}{c}\text { Peanut } \\
\text { oil [17] }\end{array}$ & $\begin{array}{c}\text { Corn } \\
\text { oil [18] }\end{array}$ & $\begin{array}{c}\text { Shea } \\
\text { butter [19] }\end{array}$ \\
\hline Physical state at room temperature & Solid & liquid & liquid & Solid \\
Saponification value (mg KOH/g) & $197-199$ & $187-190$ & $187-193$ & $169-198$ \\
Iodine value ( $\left.\mathrm{g} \mathrm{I}_{2} / \mathbf{1 0 0 g}\right)$ & $21.5-38.1$ & 118.2 & $127-133$ & $28-30$ \\
$\begin{array}{c}\text { Peroxide value (mg Eq/kg) } \\
\text { Acid value (mg NaOH/g) }\end{array}$ & $4.5-7.9$ & 2.09 & $10 \mathrm{mEq} / \mathrm{kg}(\mathrm{max})$. & $14-17$ \\
$\quad 1.2-7.3$ & - & - & $12-15$ \\
Refractive index & 1.46 & $1.46-1.465$ & 1.47 & - \\
\hline
\end{tabular}

Table 3. Physico-chemical characterization of $Q$. undulata oil produced in Senegal and Nigeria.

\begin{tabular}{ccc}
\hline Parameters & $\begin{array}{c}\text { Quassia undulata oil } \\
\text { characterization } \\
\text { in this study }\end{array}$ & $\begin{array}{c}\text { Quassia unduluta } \\
\text { oil characterization } \\
\text { by Iko et al. [21] }\end{array}$ \\
\hline Physical state at room temperature & Solid & Liquid \\
Refractive index & 1.46 & 0.7142 \\
Iodine value (gI2/100g of oil) & $21.5-38.1$ & 6.758 \\
Peroxide value $(\mathrm{mg} \mathrm{Eq} / \mathrm{kg})$ & $4.5-7.9$ & 3.759 \\
Acid value $(\mathrm{mg} \mathrm{NaOH} / \mathrm{g}$ of oil) & $1.2-7.3$ & 93.266 \\
\hline
\end{tabular}

the solvent. During the survey, the oil production was done by boiling the seed in the $P$. thonningii decoction. It appears then the $P$. thonningii leaves play a key role during the oil extraction.

\section{Conclusion}

In this paper, the Quassia undulata traditional oil extraction process by the women of Salemata in Kedougou-Senegal was established. During the survey, it appears that the oil was obtained by boiling the seed in a $P$. thonnintigi leaves decoction. Clear oil is obtained. The physicochemical characterization shows that $Q$. $u n d u$ lata oil can be used as a skin ointment and may be used as oil for food consumption after treatment.

\section{Conflicts of Interest}

The authors declare no conflicts of interest regarding the publication of this paper.

\section{References}

[1] Sarr, O., Bakhoum, A., Diatta, S. and Akpo, L.E. (2013) L'arbre en milieu soudanosahélien dans le bassin arachidier (Centre-Sénégal). Journal of Applied Biosciences, 61, 4515-4529. https://doi.org/10.4314/jab.v61i0.85598 
[2] Olovieva, O.S., Iangb, T.D.N., Ayec, A.G. and Ottea, A.T. (2004) Variabilité des caractères physico-chimiques des fruits de trois espèces ligneuses de cueillette, récoltés au Sénégal: Adansonia digitata, Balanites aegyptiaca et Tamarindus indica. Fruits, 59, 109-119. https://doi.org/10.1051/fruits:2004011

[3] Guèye, M., Kenfack, D. and Forget, P.M. (2009) Importance socio-culturelle, potentialités economiques et thérapeutiques du Carapa (Meliaceae) au Sénégal. In: van der Burgt, X., van derMaesen, J. and Onana, J.-M., Eds., Systematics and Conservation of African Plants, Royal Botanic Gardens, Kew, 357-366.

[4] Weber, N., Birnbaum, P., Forget, P., Gueye, M. and Kenfack, D. (2010) L'huile de carapa (Carapa spp., Meliaceae) en Afrique de l'Ouest: Utilisations et implications dans la conservation des peuplements naturels. Fruits, 65, 343-354.

https://doi.org/10.1051/fruits/2010029

[5] Cheek, M. and Jongkind, C.C.H. (2008) Two New Names in West-Central African Quassia L. (Simaroubaceae). Kew Bulletin, 63, 247-250. https://doi.org/10.1007/s12225-008-9022-1

[6] Sévérin, T. (1996) Information sur quelques plantes insectifuges et nematicides en Afrique tropicale: Note technique. Bulletin de la Recherche Agronomique du Bénin, $14,18-26$.

[7] Prot, J. and Kornprobst, J. (1985) Effects of Quassinoids Extracted from Hannoa undulata Seed on the Penetration and Reproduction of Meloidogyne javanica on Tomato. Revue de Nématologie, 8, 383-389.

[8] Odubanjo, V.O., Oboh, G., Oyeleye, S.I. and Adefegha, S.A. (2018) Anticholinesterase Activity and Phenolic Profile of Two Medicinal Plants (Quassia undulata and Senecio abyssinicus) Used in Managing Cognitive Dysfunction in Nigeria. Journal of Food Biochemistry, 42, e12497. https://doi.org/10.1111/jfbc.12497

[9] Odubanjo, V.O., Ibukun, G., Oboh, E.O. and Adefegha, S.A. (2018) Aqueous Extracts of Two Tropical Ethnobotanicals (Tetrapleura tetraptera and Quassia undulata) Improved Spatial and Non-Spatial Working Memories in Scopolamine-Induced Amnesic Rats: Influence of Neuronal Cholinergic and Antioxidant Systems. Biomedicine \& Pharmacotherapy, 99, 198-204. https://doi.org/10.1016/j.biopha.2018.01.043

[10] Mirailles, J., Nongonierma, R., Sagna, C. and Kornprobst, J.M. (1988) Composition en lipides et en quassinoïdes des graines de Hannoa undulata (Planch.) Simarubacée. Revue française des CORPS GRAS, 3, 13-16.

[11] Chaussod, R., Adlouni, A. and Christon, R. (2005) L'arganier et l'huile d'argane au Maroc: Vers la mutation d'un système agroforestier traditionnel? Enjeux et contribution de la recherche. Cahiers Agricultures, 14, 351-356.

[12] Kapseu, C. (2009) Production, analyse et applications des huiles végétales en Afrique. OCL_Oleagineux Corps Gras Lipides, 16, 215-229.

https://doi.org/10.1051/ocl.2009.0280

[13] Guo, Z., Vangapandu, S., Sindelar, R.D. and Walker, L.A. (2005) Biologically Active Quassinoids and Their Chemistry: Potential Leads for Drug Design. Current Medicinal Chemistry, 12, 173-190. https://doi.org/10.2174/0929867053363351

[14] Anyasor, G., Ogunwenmo, K., Oyelana, O., Ajayi, D. and Dangana, J. (2009) Chemical Analyses of Groundnut (Arachis hypogaea) Oil. Pakistan Journal of Nutrition, 8, 269-272. https://doi.org/10.3923/pjn.2009.269.272

[15] Akpan, U.G., Jimoh, A. and Mohammed, A.D. (2012) Extraction and Characterization of Castor Seed Oil. The Internet Journal of Nutrition and Wellness, 8, 43-52.

[16] Akpossan, R., Dué, E., Kouadio, J.P.E. and Kouamé, P. (2009) Valeur nutritionnelle et caractérisation physicochimique de la matière grasse de la chenille (Imbrasia 
oyemensis) séchée et vendue au marché d'Adjamé (Abidjan, Côte d'Ivoire). Journal of Animal and Plant Sciences, 3, 243-250.

[17] Siddeeg, A. and Xia, W. (2015) Oxidative Stability, Chemical Composition and Organoleptic Properties of Seinat (Cucumis melo var. tibish) Seed Oil Blends with Peanut Oil from China. Food Science and Technology, 52, 8172-8179.

https://doi.org/10.1007/s13197-015-1889-x

[18] Moreau, R.A. and Hums, M.E. (2020) Corn Oil and Distillers Corn Oil. https://doi.org/10.1002/047167849X.bio007.pub2

[19] Megnanou, R.M. and Diopoh, K.J. (2008) Caracterisation sensorielle, physico-chimique et microbiologique du beurre de Karité, Vitellaria paradoxa des marches de Cote d'Ivoire. Agronomie Africaine, 20, 221-231.

https://doi.org/10.4314/aga.v20i2.1747

[20] Haile, M., Duguma, H.T., Chameno, G. and Kuyu, C.G. (2019) Effects of Location and Extraction Solvent on Physico Chemical Properties of Moringa stenopetala Seed Oil. Heliyon, 5, e02781. https://doi.org/10.1016/j.heliyon.2019.e02781

[21] Iko, W., Sabinus, E. and Oscar, O. (2012) Physicochemical Characterization of Quassia undulata Seed Oil for Biodiesel Production. African Journal of Biotechnology, 11, 14930-14933. https://doi.org/10.5897/AJB11.1659 